\title{
Margaret McCartney: The unacceptable cost of non-NHS screening
}

\author{
Margaret McCartney general practitioner
}

Glasgow

The NHS is making impossible choices about what to fund. And yet, routinely, doctors are expected to pick up the pieces from non-NHS services.

I've written before about my distaste for private health screening companies, which, after frightening citizens into their offices and relieving them of hundreds of pounds, hand back false positives and reams of thoughtless testing to the NHS. GPs have to sort this out, which costs the NHS, even though it wouldn't have recommended the tests to start with.

Screening apparently healthy people may sound logical if you have no interest in lead time bias, Wilson and Jungner, or cost effectiveness. Several prostate cancer charities offer prostate specific antigen (PSA) screening in football stadiums and at Rotary clubs. Leaflets recommend that "every man aged 45 or over should have a PSA test" and that men who don't should "take your head out of the sand" and "wise up."

The NHS funds PSA testing on request, but this is a fudge: the NHS doesn't recommend population PSA screening, ${ }^{1}$ and the charity leaflets I've seen don't refer men to the decision aids available on the NHS. ${ }^{2}$ Prostate Cancer UK recommends screening well beyond the limits that the NHS funds. ${ }^{3}$

Meanwhile, the charity Cardiac Risk in the Young operates at schools, rugby clubs, and the occasional NHS venue, ${ }^{4}$ sometimes charging $£ 35$ for the electrocardiograms they arrange because "at least 12 young people aged 14-35 die every week in the UK from undiagnosed cardiac conditions. The majority of these deaths are preventable." 5

Private screening companies, frightening citizens into their offices and relieving them of hundreds of pounds, hand back reams of thoughtless testing to the NHS

However, the UK National Screening Committee reviewed the evidence in 2015, concluding that "there is very little research into the reliability of the tests for identifying those at risk of SCD [sudden cardiac death]" and finding uncertainties in "the overall benefit of identifying those at risk when weighed against the potential harms." Therefore, the committee says that it "cannot recommend its use in a [population] screening programme."

I have sympathy for people who have experienced dreadful loss and who want to help others. But offering this as a solution creates problems.

Firstly, offering non-NHS recommended tests creates false reassurance and a medical cul-de-sac. If people think that a problem's being fixed when it isn't, we do harm. Secondly, people are not given fair information to make a choice for themselves. And, thirdly, the NHS shouldn't be used as kitchen roll, to absorb the mess and overspill from well intentioned but poorly evidenced activities elsewhere.

When the NHS is so careful with its own deliberations on cost effectiveness, it shouldn't be hijacked into accepting external fall-out and follow-up. It's time to place a financial levy on all providers who expect NHS pick-up without upholding NHS standards.

\section{Competing interests: See www.bmj.com/about-bmj/freelance-} contributors/margaret-mccartney.

Provenance and peer review: Commissioned; not externally peer reviewed.

1 UK National Screening Committee. The UK NSC recommendation on prostate cancer screening/PSA testing in men over the age of 50. Jan 2016. http://legacy.screening.nhs. uk/prostatecancer.

2 NHS Shared Decision Making Decision aids. http $/ / /$ sdm rightcare.nhs.uk/pda/.

3 Prostate Cancer UK. Consensus on PSA testing. http://prostatecanceruk.org/about-us/ what-we-think-and-do/consensus-on-psa-testing.

4 Cardiac Risk in the Young. Test my heart: UK screening service. www.testmyheart.org. 5 Cardiac Risk in the Young. Who are CRY and why is cardiac testing important? Available at www.c-r-y.org.uk.

6 UK National Screening Committee. The UK NSC recommendation on screening to preven sudden cardiac death in 12 to 39 year olds. Jul 2015. http://legacy.screening.nhs.uk/ suddencardiacdeath.

Published by the BMJ Publishing Group Limited. For permission to use (where not already granted under a licence) please go to http://group.bmj.com/group/rights-licensing/ permissions 